\title{
Comparative Prevalence of Ectoparasitic Fauna on Birds from Selected Mainland and Island of Sarawak
}

\author{
RAJA NUR ATIQAH RAJA AZIZI \& MADINAH ADRUS*
}

\author{
Faculty of Resource Science and Technology, Universiti Malaysia Sarawak, 94300 Kota Samarahan, Sarawak, \\ Malaysia \\ *Corresponding author: amadinah@unimas.my
}

\begin{abstract}
A survey of ectoparasitic fauna on birds was conducted in October 2017 until January 2018. The aims of this study were to investigate the ectoparasitic fauna on birds and to compare its prevalence in the selected mainland and island of Sarawak. A series of sampling by using mist-net has been done in Mount Sadong and Satang Besar Island with a total of 1440 hours of sampling effort for each locality. A total of 53 individuals of birds were captured and examined for its ectoparasites. Twenty-one species of ectoparasites were recorded comprising four species of lice and 17 species of mites. Four species of lice and 11 species of mites were detected in Mount Sadong while eight species of mites and no lice were detected in Satang Besar Island. The prevalence of ectoparasites infested on birds in Mount Sadong (33.33\%) was higher than Satang Besar Island $(17.39 \%)$. The $p$-value $(\mathrm{p}=0.474)$ indicated there was no significant difference between the prevalence of ectoparasites from both localities. The result is important since ectoparasites infestation could affect the survival of birds and has the potential transmission of zoonotic disease.
\end{abstract}

Keywords: Bird, ectoparasites, island, mainland, prevalence, Sarawak

Copyright: This is an open access article distributed under the terms of the CC-BY-NC-SA (Creative Commons Attribution-NonCommercialShareAlike 4.0 International License) which permits unrestricted use, distribution, and reproduction in any medium, for non-commercial purposes, provided the original work of the author(s) is properly cited.

\section{INTRODUCTION}

Borneo is a huge landmass that provides a home to the biodiversity of tropical life which occupied more than 650 species of birds in which 52 species of them are endemic (Myers, 2016). Birds are the most successful vertebrate group among the others and play their important role as predators, pollinators, scavengers, seed dispersers, and ecosystem engineers (Whelan, Wenny \& Marquis, 2008). However, the bird richness may have affected by the distance between the island and the nearest mainland as only certain bird species or families have the ability to disperse far away to the islands (Dalsgaard et al., 2014). This factor may cause remote islands to have smaller numbers of species than the mainland (Kalmar \& Currie, 2006; Kier et al., 2009; Simberloff, 1995). Thus, the ectoparasites on birds in the island may tend to have a lower prevalence than the mainland as they increase their preference to one or a few specific hosts due to the limited diversity of birds.

A study by Brown, Brown and Rannala (1995) reported the parasitised birds had an annual survivorship $12 \%$ lower than non-parasitised birds. Their findings indicated that the ectoparasites infestation could affect the long-term survival of their host (Sajid \& Ehsan, 2017). However, the study of the ectoparasitic fauna on birds was given less priority and almost neglected, due to less contact with human and they are not subjected to sources of protein for human. To date, there is still lacking published data on ectoparasites of birds available in Malaysia in which most of the studies were pertaining to Peninsular Malaysia. In addition, most of the publications locally are subjected to consumable poultry. Therefore, this study is intended to recover the ectoparasitic fauna on the birds and compare their prevalence from selected mainland and island in Sarawak to serve as preliminary references for future understanding on the ecological role of ectoparasites in regulation of population of birds as well as to develop the conservation not solely on bird species but also their habitats.

\section{MATERIALS \& METHODS Sampling Sites}

This study has been conducted within October 2017 to January 2018 in Mount Sadong (1.21 $\left.{ }^{\circ} \mathrm{N}, 110.50{ }^{\circ} \mathrm{E}\right)$ and Satang Besar Island $\left(1.79^{\circ} \mathrm{N}, 110.17^{\circ} \mathrm{E}\right)$ (Figure 1). Mount Sadong was considered as a secondary forest that consists of bamboo vegetation, orchards, and small bark trees. This study covered the foothill of the mountain to the hilly area. Satang Besar Island was also considered as a secondary forest which consists of bamboo, small bark trees and the forest floor were mostly covered with leaf litter. This study was covered the island edges to the hilly area. 


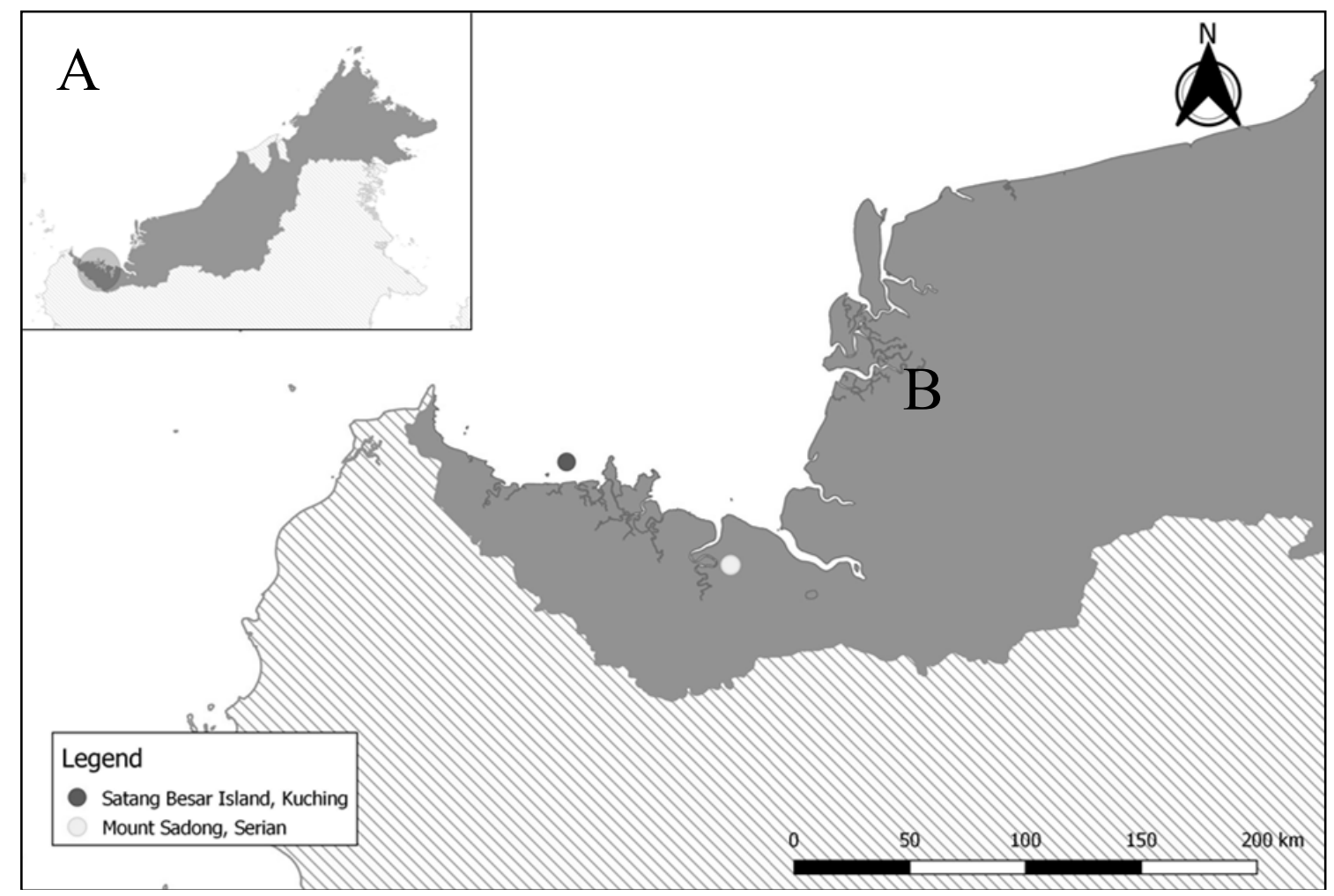

Figure 1. A - Malaysian Borneo of Sabah and Sarawak; B - The tip of Sarawak and two localities where ectoparasites of birds in mainland and island were sampled. (Source: QGIS software)

\section{Sample Collection}

Fifteen mist nets were set in Mount Sadong and 30 mist nets were set in Pulau Satang Besar to maximise and balance the sampling efforts for both sides (total effort of 1440 sampling hours). The mist nets were checked once every two hours' interval from 0600 to 1800 hours. Each bird trapped in the mist net was removed and placed in a cleaned cloth bag to prevent contamination of ectoparasites to the other host. The identification of birds was conducted based on Phillipps and Phillipps (2014), and Myers (2016). Each bird was ringed with a specific identification number on tarsus to avoid reassessment. The birds were scanned by visual examination and the ectoparasites were collected by using forceps from the different body parts of the bird. The ectoparasites of each bird were preserved in a vial containing $70 \%$ ethanol separately with the label of ring number, host species, sex, location, date of collection and the collector's name. Then, the examined birds were released and all collected ectoparasites have been brought to the Parasitology laboratory, Universiti Malaysia Sarawak for further identification.

\section{Mounting \& Identification}

The mounting process followed Madinah, Abang, Mariana and Abdullah (2011) with some modifications. The ectoparasites were sorted accordingly based on their morphology under a stereomicroscope. All ectoparasites were prepared by soaking in lactophenol (clearing agent) solution at room temperature for three hours depends on the size before mounting in Canada Balsam. The mounted slides were incubated at room temperature for a week to harden the mounting medium. Then, mounted ectoparasites were observed under a compound microscope and identified to genera and species level as possible according to the keys and illustrations offered by Atyeo and Peterson (1970), Constantinescu, Chişamera, Mukhim and Adam (2014) and Price and Graham (1997).

\section{Data Analysis}

Statistical analyses were performed using PAST Software version 3.20 following Hammer (2000). Two-sample $t$ test was used to explore the differences in prevalence among the two habitats. The $p$-values below 0.05 were considered as significant. A probability value of less than 0.05 was considered statistically significant. 


\section{RESULT}

\section{Host Collection}

A total of 53 individuals of birds comprising 20 species from 12 families were captured from both the mainland and island (Table 1) were examined for its ectoparasites. Mount Sadong recorded a total of 30 individuals of birds captured which consists of 14 species from nine different families while a total of 23 individuals of birds were captured from the Satang Besar Island which consist of nine species from eight different families. The most abundant species captured in Mount Sadong was Little Spiderhunter (Arachnothera longirostra) with a total of nine individuals. Differ in Satang Besar Island, the most abundant species captured was Olive-winged Bulbul (Pycnonotus plumosus) with a total of 12 individuals. Based on the Wild Life Protection Ordinance (WLPO) 1998, five out of 20 species of birds captured were categorised as "Protected" species and the rest was not listed in any schedule in WLPO 1998. Meanwhile, based on the International Union for Nature (IUCN) Red List of Threatened Species 2017-3, Roul roul (Rollulus rouloul) and Green Broadbill (Calyptomena viridis) was listed as "Near Threatened", nine out of 20 species captured were "Least Concerned" and only Chesnut-winged Babbler (Stachyris erythroptera) was still not evaluated.

Table 1. List of bird species caught in both Pulau Satang Besar and Mount Sadong.

\begin{tabular}{|c|c|c|c|c|c|c|}
\hline Order/ Family & Common/Species name & WLPO 1998 & IUCN 2017 & MS & SBI & Total \\
\hline \multicolumn{7}{|l|}{ Columbiformes } \\
\hline Columbidae & $\begin{array}{l}\text { Emerald Dove } \\
\text { Chalcophaps indica }\end{array}$ & NL & $\mathrm{LC}$ & 4 & 2 & 6 \\
\hline \multicolumn{7}{|l|}{ Coraciiformes } \\
\hline \multirow[t]{2}{*}{ Alcedinidae } & $\begin{array}{l}\text { Rufous-backed Kingfisher } \\
\text { Ceyx erithaca }\end{array}$ & $\mathrm{P}$ & $\mathrm{LC}$ & 3 & 0 & 3 \\
\hline & $\begin{array}{l}\text { Stork-billed Kingfisher } \\
\text { Pelargopsis capensis }\end{array}$ & $\mathrm{P}$ & $\mathrm{LC}$ & 0 & 1 & 1 \\
\hline \multicolumn{7}{|l|}{ Cuculiformes } \\
\hline \multirow[t]{2}{*}{ Cuculidae } & $\begin{array}{l}\text { Chestnut-winged Cuckoo } \\
\text { Clamator coromandus }\end{array}$ & NL & $\mathrm{LC}$ & 0 & 1 & 1 \\
\hline & $\begin{array}{l}\text { Hodgson's Hawk Cuckoo } \\
\text { Hierococcyx nisicolor }\end{array}$ & NL & $\mathrm{LC}$ & 0 & 2 & 2 \\
\hline \multicolumn{7}{|l|}{ Galliformes } \\
\hline Phasianidae & $\begin{array}{l}\text { Roul roul } \\
\text { Rollulus rouloul }\end{array}$ & $\mathrm{p}$ & NT & 2 & 0 & 2 \\
\hline \multicolumn{7}{|l|}{ Passeriformes } \\
\hline Eurylaimidae & $\begin{array}{l}\text { Green Broadbill } \\
\text { Calyptomena viridis }\end{array}$ & NL & NT & 2 & 0 & 2 \\
\hline Laniidae & $\begin{array}{l}\text { Tiger Shrike } \\
\text { Lanius Tigrinus }\end{array}$ & NL & $\mathrm{LC}$ & 0 & 1 & 1 \\
\hline \multirow[t]{2}{*}{ Muscicapidae } & $\begin{array}{l}\text { Blue-and-white Flycatcher } \\
\text { Cyanoptila cyanomelana }\end{array}$ & NL & $\mathrm{LC}$ & 1 & 0 & 1 \\
\hline & $\begin{array}{l}\text { White-rumped Shama } \\
\text { Copsychus malabaricus }\end{array}$ & $\mathrm{P}$ & $\mathrm{LC}$ & 1 & 2 & 3 \\
\hline \multirow[t]{4}{*}{ Nectariniidae } & $\begin{array}{l}\text { Brown-throated Sunbird } \\
\text { Anthreptes malacensis }\end{array}$ & NL & $\mathrm{LC}$ & 1 & 1 & 2 \\
\hline & $\begin{array}{l}\text { Little Spiderhunter } \\
\text { Arachnothera longirostra }\end{array}$ & NL & $\mathrm{LC}$ & 9 & 0 & 9 \\
\hline & $\begin{array}{l}\text { Purple-naped Sunbird } \\
\text { Hypogramma hypogrammicum }\end{array}$ & NL & $\mathrm{LC}$ & 1 & 0 & 1 \\
\hline & $\begin{array}{l}\text { Yellow-eared Spiderhunter } \\
\text { Arachnothera chrysogenys }\end{array}$ & NL & $\mathrm{LC}$ & 1 & 0 & 1 \\
\hline \multirow[t]{2}{*}{ Pycnonotidae } & $\begin{array}{l}\text { Cream-vented Bulbul } \\
\text { Pycnonotus simplex }\end{array}$ & NL & $\mathrm{LC}$ & 1 & 0 & 1 \\
\hline & $\begin{array}{l}\text { Olive-winged Bulbul } \\
\text { Pycnonotus plumosus }\end{array}$ & NL & $\mathrm{LC}$ & 0 & 12 & 12 \\
\hline \multirow[t]{2}{*}{ Timaliidae } & $\begin{array}{l}\text { Chesnut-winged Babbler } \\
\text { Stachyris erythroptera }\end{array}$ & NL & NE & 1 & 0 & 1 \\
\hline & $\begin{array}{l}\text { Grey-headed Babbler } \\
\text { Stachyris poliocephala }\end{array}$ & NL & $\mathrm{LC}$ & 1 & 0 & 1 \\
\hline Rhipiduridae & $\begin{array}{l}\text { Pied Fantail } \\
\text { Rhipidura javanica }\end{array}$ & NL & $\mathrm{LC}$ & 0 & 1 & 1 \\
\hline \multicolumn{7}{|l|}{ Piciformes } \\
\hline Picidae & $\begin{array}{l}\text { Rufous Piculet } \\
\text { Sasia abnormis }\end{array}$ & $\mathrm{P}$ & $\mathrm{LC}$ & 2 & 0 & 2 \\
\hline TOTAL & & & & 30 & 23 & 53 \\
\hline
\end{tabular}

Keys: IUCN - IUCN Red List of Threatened Species 2017-3 (Red Data Book); WLPO - Sarawak Wild Life Protection Ordinance 1998; SBI

- Satang Besar Island; MS - Mount Sadong; P - Protected; NL - Not Listed; NT - Near Threatened; LC - Least Concern; NE - Not Evaluated. 


\section{Prevalence of Ectoparasite Species}

Two groups of ectoparasites were discovered from the birds captured which are lice and mites. A total of 354 individuals belongs to 21 species of ectoparasites were collected from birds in both localities comprising four species of lice and 17 species of mites (Table 2). Fifteen species of ectoparasites (four species of lice and 11 species of mites) were recorded in Mount Sadong while eight species of ectoparasites (all mites) were recorded in Satang Besar Island. White-rumped Shama (Copsychus malabaricus) was reported to have the largest number of ectoparasites individuals with a total of 109 ectoparasite individuals and Pied Fantail (Rhipidura javanica) with a total of 79 individuals of ectoparasites for mainland and island respectively. The highest recorded number of ectoparasites species in both localities was Trouessartia sp. with a total number of 236 individuals.

The highest recorded prevalence of ectoparasites (Table 3) in the mainland was Trouessartia sp. (10\%) followed by Lipeurus sp. and Philopteroides sp. (both 6.67\%) then by the other ectoparasites (3.33\%). For the island, the ectoparasites that hold the highest prevalence were similar to the mainland, Trouessartia sp. (17.39\%) then followed by the other ectoparasites (4.35\%). Overall, there were 10 birds were infested with ectoparasites (33.33\%) in Mount Sadong with the mean intensity value of 24.2 and only four out of 23 individuals examined in Satang Besar Island were infested by ectoparasites (17.39\%) with the mean intensity value of 29.5 . Considering all ectoparasites, there were no significant differences in the prevalence of ectoparasites between both sites $(p=0.474)$.

\section{DISCUSSION}

In this study, 14 species of birds were recorded from Mount Sadong which is comparatively equivalent to the previous study conducted in several mainlands of Sarawak, with a number of 27 to 35 species of birds were reported (Sodhi, 2002; Tuen et al., 2006). However, only nine species of birds were recorded in Satang Besar Island. Simberloff (2000) explained the lower number of species in the islands than in the mainland was due to reduce in area, increase isolation to nearby mainland and lack of habitat present. The most abundant bird in Mount Sadong was Little Spiderhunter (Arachnothera longirostra) with a total of nine individuals recorded. According to Davison and Chew (2016), this nectarivore species is common and most numerous in plantain garden, which compatible to orchard vegetation in Mount Sadong. The most abundant species captured in Satang Besar Island was Olive-winged Bulbul (Pycnonotus plumosus) with a total of 12 individuals. This insectivore and frugivore species inhabit forest edges and also present in island habitat (Davison \& Chew, 2016), which matched the sampling site in Satang Besar Island that covered from the forest edges to the hilly area.

In Malaysia, the study of ectoparasites on birds was given less priority due to not subjected to pest management of poultry. The publication on avian ectoparasites still low in number locally. In this study, ectoparasites found were categorised in two groups of arthropods namely lice and mites. Evidently, 21 species of ectoparasites have been recorded from both localities which consist of 15 species of ectoparasites recorded in Mount Sadong. Meanwhile, only eight species of ectoparasites were recorded in Satang Besar Island. Rusli (2007) recorded 20 species of ectoparasites on birds in oil palm plantation. Meanwhile, eight species of ectoparasites on birds have been reported by Asrif, Nurqamareena and Chong (2018) in rice field. It is remarkable that different ectoparasites species were found in different populations (Barrientos, Valera, Barbosa, Carrillo \& Moreno, 2014). This might due to host diversity, behaviour, morphology, geographic range and life history (Hughes \& Page, 2007).

The presence of lice could be explained by the presence of their host, this cannot be argued for the no lice recorded on the island. Lice are permanent ectoparasites in which they complete their entire life cycle on the host body (Johnson \& Clayton, 2003; Marshall, 1981; Murray, 1990; Rozsa, 1997). For instance, Lipeurus sp. and Goniodes sp. Have the same host group which is the Old World gallinaceous birds (Price \& Graham, 1997). This was approved by several previous studies found on domestic chickens and turkeys (Rahman \& Haziqah, 2015; Zarith, Suhaila, Izzauddin \& Khadijah, 2018) and also wild chicken in Thailand, Laos, and the Philippine Islands (Price \& Graham, 1997). In this study, both ectoparasite species were found only on Roul roul (Rollulus rouloul) which is a member of family Phasianidae from order Galliformes, the gallinaceous birds. In this study, Roul roul (Rollulus rouloul) was only present on the mainland, thus revealed the reason for the absent of Lipeurus sp. and Goniodes sp. in the island.

The Trouessartia chionidis were present in both habitats. Evidently, their infestation was subjected to host from Family Muscicapidae with high number of individuals and one individual was found on Yellow-eared Spiderhunter (Arachnothera chrysogenys) from Family Nectaritiidae. Lyra-Neves, Farias and Telino-Júnior (2003) have been mentioning that feather mites are very specific to birds' families, genera, and even species. Genus Trouessartia is exclusively associated with their passerine host (Minorov \& Kopij, 2000). In this study, the birds that infested by Trouessartia chionidis, were White-rumped Shama (Copsychus malabaricus), Blue-and-white Flycatcher (Cyanoptila cyanomelana), Pied Fantail (Rhipidura javanica) and the Yellow-eared Spiderhunter (Arachnothera 
Table 2. The number of ectoparasite individuals collected on its host in Mount Sadong and Satang Besar Island.

\begin{tabular}{|c|c|c|c|c|c|c|c|c|c|c|c|c|c|c|c|c|c|c|c|c|c|c|c|c|c|}
\hline & \multirow[b]{3}{*}{ Ectoparasites } & \multicolumn{23}{|c|}{ Host } & \multirow[b]{3}{*}{ Total } \\
\hline & & \multicolumn{14}{|c|}{ Mainland } & \multicolumn{9}{|c|}{ Island } & \\
\hline & & 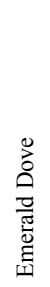 & 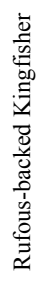 & 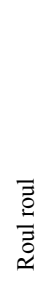 & 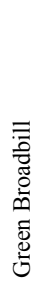 & 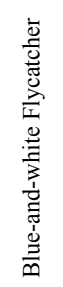 & 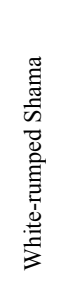 & 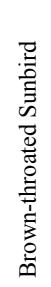 & 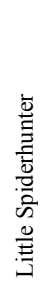 & 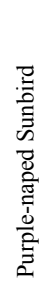 & 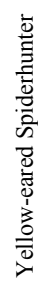 & 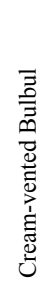 & 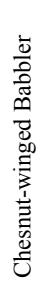 & 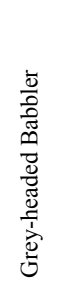 & 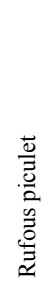 & 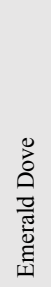 & 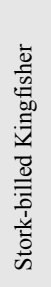 & 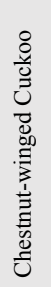 & 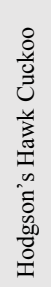 & 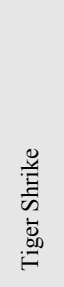 & 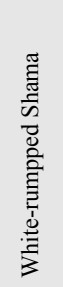 & 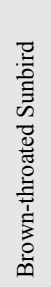 & 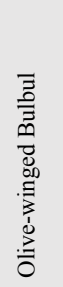 & 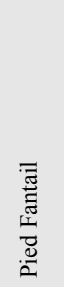 & \\
\hline \multirow{6}{*}{ 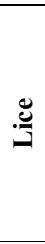 } & Philopteridae & & & & & & & & & & & & & & & & & & & & & & & & \\
\hline & Lipeurus sp. & - & - & 3 & - & - & - & - & - & - & - & - & - & - & - & - & - & - & - & - & - & - & - & - & 3 \\
\hline & Philopteroides sp. & - & 6 & - & - & - & - & - & - & - & - & - & - & - & - & - & - & - & - & - & - & - & - & - & 6 \\
\hline & Sp. 4 & 1 & - & - & - & - & - & - & - & - & - & - & - & - & - & - & - & - & - & - & - & - & - & - & 1 \\
\hline & Goniodidae & & & & & & & & & & & & & & & & & & & & & & & & \\
\hline & Goniodes sp. & - & - & 1 & - & - & - & - & - & - & - & - & - & - & - & - & - & - & - & - & - & - & - & - & 1 \\
\hline \multirow{22}{*}{ 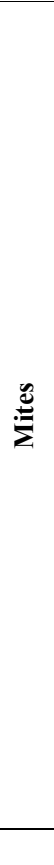 } & Dermanyssidae & & & & & & & & & & & & & & & & & & & & & & & & \\
\hline & Dermanyssus sp. & - & - & - & - & - & - & - & 1 & - & - & - & - & - & - & - & - & - & - & - & - & - & - & - & 1 \\
\hline & Proctophyllodidae & & & & & & & & & & & & & & & & & & & & & & & & \\
\hline & Pedanodectes angustilobus & - & - & - & - & - & - & - & - & - & 6 & - & - & - & - & - & - & - & - & - & - & - & - & - & 6 \\
\hline & Proctophyllodes glandarinus & - & - & - & - & - & - & - & - & - & - & - & - & - & 7 & - & - & - & - & - & - & - & - & - & 7 \\
\hline & Proctophyllodes sp. & - & - & - & - & 3 & - & - & - & - & - & - & - & - & - & - & - & - & - & - & - & - & - & 6 & 9 \\
\hline & Pterodectes sp. 1 & - & - & - & - & - & - & - & - & - & - & - & - & - & - & - & - & - & - & - & - & - & 2 & - & 2 \\
\hline & Pterodectes sp. 2 & - & - & - & - & - & - & - & - & - & - & - & - & - & - & - & - & - & - & - & 3 & - & - & - & 3 \\
\hline & Pterodectes sp. 3 & - & - & - & - & - & - & - & - & - & - & - & - & - & - & - & - & - & - & - & 6 & - & - & - & 6 \\
\hline & Trouessartiidae & & & & & & & & & & & & & & & & & & & & & & & & \\
\hline & Trouessartia chionidis & - & - & - & - & 98 & 57 & - & - & - & 1 & - & - & - & - & - & - & - & - & - & 26 & - & - & 53 & 236 \\
\hline & Trouessartia sp. 1 & - & - & - & - & - & 52 & - & - & - & - & - & - & - & - & - & - & - & - & - & - & - & - & - & 52 \\
\hline & Trouessartia sp. 2 & - & - & - & - & - & - & - & - & - & - & - & - & - & - & - & - & - & - & - & - & - & - & 15 & 15 \\
\hline & Unidentified species & & & & & & & & & & & & & & & & & & & & & & & & \\
\hline & Sp. 11 & - & - & 1 & - & - & - & - & - & - & - & - & - & - & - & - & - & - & - & - & - & - & - & - & 1 \\
\hline & Sp. 12 & - & - & 2 & - & - & - & - & - & - & - & - & - & - & - & - & - & - & - & - & - & - & - & - & 2 \\
\hline & Sp. 13 & - & - & 1 & - & - & - & - & - & - & - & - & - & - & - & - & - & - & - & - & - & - & - & - & 1 \\
\hline & Sp. 14 & - & - & 1 & - & - & - & - & - & - & - & - & - & - & - & - & - & - & - & - & - & - & - & - & 1 \\
\hline & Sp. 15 & - & - & 1 & - & - & - & - & - & - & - & - & - & - & - & - & - & - & - & - & - & - & - & - & 1 \\
\hline & Sp. 19 & - & - & - & - & - & - & - & - & - & - & - & - & - & - & - & - & - & - & - & - & - & 2 & - & 2 \\
\hline & Sp. 21 & - & - & - & - & - & - & - & - & - & - & - & - & - & - & - & - & - & - & - & - & - & - & 4 & 4 \\
\hline & TOTAL & 1 & 1 & 10 & 0 & 101 & 109 & 0 & 0 & 0 & 7 & 0 & 0 & 0 & 7 & 0 & 0 & 0 & 0 & 0 & 35 & 0 & 4 & 79 & 354 \\
\hline
\end{tabular}


Table 3. Prevalence and mean intensity of ectoparasite infested on birds in Mount Sadong and Satang Besar Island.

\begin{tabular}{|c|c|c|c|c|c|c|c|c|c|}
\hline \multicolumn{2}{|r|}{ Ectoparasites } & \multicolumn{4}{|c|}{ Mainland $(\mathrm{N}=30)$} & \multicolumn{4}{|c|}{ Island $(\mathrm{N}=23)$} \\
\hline & & Infested host & $\begin{array}{c}\text { Ectoparasites prevalence } \\
(\%)\end{array}$ & $\begin{array}{c}\text { Number of } \\
\text { ectoparasites }\end{array}$ & Mean intensity & Infested host & $\begin{array}{c}\text { Ectoparasites prevalence } \\
(\%)\end{array}$ & $\begin{array}{c}\text { Number of } \\
\text { ectoparasites }\end{array}$ & Mean intensity \\
\hline \multirow{6}{*}{$\stackrel{\mathscr{\Xi}}{\Xi}$} & Philopteridae & & & & & & & & \\
\hline & Lipeurus sp. & 2 & 6.67 & 3 & 1.50 & 0 & 0 & 0 & 0.00 \\
\hline & Philopteroides sp. & 2 & 6.67 & 6 & 3.00 & 0 & 0 & 0 & 0.00 \\
\hline & Sp. 4 & 1 & 3.33 & 1 & 1.00 & 0 & 0 & 0 & 0.00 \\
\hline & Goniodidae & & & & & & & & \\
\hline & Goniodes sp. & 1 & 3.33 & 1 & 1.00 & 0 & 0 & 0 & 0.00 \\
\hline \multirow{22}{*}{ 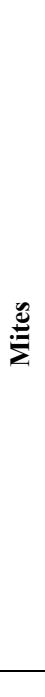 } & Dermanyssidae & & & & & & & & \\
\hline & Dermanyssus sp. & 1 & 3.33 & 1 & 1.00 & 0 & 0 & 0 & 0.00 \\
\hline & Proctophyllodidae & & & & & & & & \\
\hline & Pedanodectes. angustilobus & 1 & 3.33 & 6 & 6.00 & 0 & 0 & 0 & 0.00 \\
\hline & Proctophyllodes. glandarinus & 1 & 3.33 & 7 & 7.00 & 0 & 0 & 0 & 0.00 \\
\hline & Proctophyllodes sp. & 1 & 3.33 & 3 & 3.00 & 1 & 4.35 & 6 & 6.00 \\
\hline & Pterodectes sp. 1 & 0 & 0 & 0 & 0.00 & 1 & 4.35 & 2 & 2.00 \\
\hline & Pterodectes sp. 2 & 0 & 0 & 0 & 0.00 & 1 & 4.35 & 3 & 3.00 \\
\hline & Pterodectes sp. 3 & 0 & 0 & 0 & 0.00 & 1 & 4.35 & 6 & 6.00 \\
\hline & Trouessartiidae & & & & & & & & \\
\hline & Trouessartia chionidis & 3 & 10.00 & 156 & 52.00 & 4 & 17.39 & 80 & 20.00 \\
\hline & Trouessartia sp. 1 & 1 & 3.33 & 52 & 52.00 & 0 & 0 & 0 & 0.00 \\
\hline & Trouessartia sp. 2 & 0 & 0 & 0 & 0.00 & 1 & 4.35 & 15 & 15.00 \\
\hline & Unidentified species & & & & & & & & \\
\hline & Sp. 11 & 1 & 3.33 & 1 & 1.00 & 0 & 0 & 0 & 0.00 \\
\hline & Sp. 12 & 1 & 3.33 & 2 & 2.00 & 0 & 0 & 0 & 0.00 \\
\hline & Sp. 13 & 1 & 3.33 & 1 & 1.00 & 0 & 0 & 0 & 0.00 \\
\hline & Sp. 14 & 1 & 3.33 & 1 & 1.00 & 0 & 0 & 0 & 0.00 \\
\hline & Sp. 15 & 1 & 3.33 & 1 & 1.00 & 0 & 0 & 0 & 0.00 \\
\hline & Sp. 19 & 0 & 0 & 0 & 0.00 & 1 & 4.35 & 2 & 2.00 \\
\hline & Sp. 21 & 0 & 0 & 0 & 0.00 & 1 & 4.35 & 4 & 4.00 \\
\hline & Overall & 10 & 33.33 & 242 & 24.2 & 4 & 17.39 & 118 & 29.5 \\
\hline
\end{tabular}


chrysogenys) which were all belong to Order Passeriformes. Thus, it is possible for Trouessartia chionidis to be present in both habitats as their host available in both habitats.

However, they differed in the number of individuals of Trouessartia chionidis were observed from both habitats. Mount Sadong recorded 156 individuals of Trouessartia chionidis and Satang Besar Island while only 59 individuals of Trouessartia chionidis recorded. Previous study has found a poor parasite assemblage in the islands compared to the mainland (Barrientos et al., 2014). There was general agreement about the reduced number of ectoparasites expected for island-dwelling and the density of host seems to be the factor (Barrientos et al., 2014). The number of ectoparasites is also influenced by body maintenance behaviour (Clayton, Koop, Harbison, Moyer \& Bush, 2010). As for example, Roul roul (Rollulus rouloul) recorded the most ectoparasites species among the other host, but in lower number of ectoparasites individuals. This might due to their dusting behaviour (Clayton et al., 2010). According to Van Liere (1992) and Clayton et al. (2010), dusting is a way to remove excess feather oil that can cause matting of plumage and also helpful in controlling ectoparasites by reducing feather lipids (food for some ectoparasite), directly dislodging ectoparasites and block ectoparasite's spiracles for breathing. Other adaptations and behaviours also might be helpful in controlling ectoparasites such as plumage barrier, feathers toxins, and nest maintenance behaviour (Clayton et al., 2010).

Satang Besar Island recorded a low prevalence (17.30\%) compared to Mount Sadong (33.33\%). A general low prevalence of ectoparasites in the island was agreed with works reporting the low prevalence of ectoparasites in island habitats by Hellgren, Križanauskienė, Hasselquist and Bensch (2011). Yet, other author has reported otherwise, the majority of the parasite species on the islands did not show a reduced prevalence of infestation compared to mainland sites (Paterson, 2012). Various hypotheses may account for the prevalence of avian ectoparasites in the mainland and island. Fromont, Morvilliers, Artois and Pontier (2001) stated that the mainland population often has higher directly transmitted parasites than island populations. This might due to the higher density of host in mainland (Barrientos et al., 2014; Stanko, Miklisová, de Bellocq, \& Morand, 2002). As could be described the habitat of mainland in this study, Mount Sadong was a forest that was surrounded by fruits and pepper orchards that provide unlimited food sources to vertebrates. This type of vegetation provided a good habitat for birds (which proven by the higher number of bird individuals $(\mathrm{N}=30)$ captured compared to Satang Besar Island) and beneficial for ectoparasites to harbour their colony on the host. Whereas the absence of some species with low prevalence could be explained by the low sample size of the host on the island.

The low prevalence of ectoparasites of birds on the island may be due to host species available on the island or specifically due to degree of host preferences (Barrientos et al., 2014). Some of them used an array of those belonging to the same order or family (McCoy, Léger \& Dietrich, 2013). The result from this study shows the infestation of ectoparasites in Satang Besar Island was lower than infestation in Mount Sadong. However, there was higher in mean intensity (29.5) than mainland (24.2) which indicates that a high number of ectoparasites tend to inhabit on an infected host in the island. Due to the low host available and high degree of host preference, the infestation of ectoparasites in the island was occurring only on White-rumped Shama, Olive-winged Bulbul and Pied Fantail which solely subjected to order Passeriformes.

Apart from that, ectoparasites prevalence might also be influenced by land size. This was supported by the previous study by Lindström, Foufopoulos, Pärn and Wikelski (2004) in which ectoparasite prevalence infestation increased with the land size. This seems applicable to this study since the island has a smaller land size than the mainland. Thus, smaller land size limits the dispersal ability of the ectoparasites (Plaisance, Rousset, Morand \& Littlewood, 2008). Other than that, the increase of ectoparasite prevalence with the land size is most likely to be explained with the increasing of the avian host population size that inhabits the land (Lindström et al., 2004). Therefore, an increased number of contacts between hosts will increase ectoparasite transmission in the particular land (Dobson \& Carper 1996; Lindström et al., 2004).

The prevalence of ectoparasites might depend on the nutritional status of the host (Tschirren, Bischoff, Saladin \& Richner, 2007). In this study, there is a high infestation of feather mites on insectivores bird (Family Muscicapidae) and low infestation on nectarivores bird (Family Nectariidae). Feather mites are known to feed mainly on uropygial gland oil of birds (Galván et al., 2008). Uropygial gland secretion functions in maintaining the keratine in feathers, which keep the feathers in a good condition and flexible (Reynold, 2013; Stettenheim, 2000). Therefore, insectivores bird would have a larger uropygial gland than nectarivores bird for feathers maintenance as it is important for flight during predation (Reynold, 2013). Thus, the mites infestation is increasing with the size of the uropygial gland of the host (Galván et al., 2008).

Considering all ectoparasites species, $t$-test result indicated there was no significant difference in prevalence of the ectoparasitic fauna on birds between Mount Sadong and Satang Besar Island. The result in this study was expected to free from biases because the sampling effort was the same in both localities and the data was obtained with 
standard methodologies, not from the other external sources. The indicated $t$-test result might due to the low sample size of the host. Insufficient sampling days may serve in the low host collection. More sampling days are needed to increase host captured.

The unidentified species of ectoparasites were due to inappropriate handling of the specimens during collection, sorting and mounting which cause damage to the crucial body part for identification. The unidentified species can only be identified as mites. Identification of parasites is a critical phase of this study. A sufficient illustration key is an important tool in the identification of ectoparasites. This study offers the first list of ectoparasitic fauna on birds in island population and also provides a preliminary data of the ectoparasitic fauna on birds in Sarawak. This study is important since ectoparasites infestation could affect the survival of birds and has the potential transmission of zoonotic disease.

\section{CONCLUSION}

In this study, Mount Sadong recorded higher in numerical prevalence of ectoparasites on bird than Satang Besar Island with were both dominated by Trouessartia chionidis. The prevalence of ectoparasites on bird is different according to the host density, degree of host preferences, land size, and nutritional status of the host. There was no significant difference between the prevalence of the ectoparasitic fauna on birds in the selected mainland and island of Sarawak. The result of this study might not be as comparable as other prevalence studies since it obtained low sample size of the host. A larger sample size of hosts is needed to support the study of ectoparasites prevalence. A sufficient key manual is crucial in conducting the ectoparasites study. This study provides a preliminary comparative data on ectoparasites in mainland and island of Sarawak. Besides, this data might be useful for the respective authority as an additional information for the conservation purposes of birds and its habitats. Thus, more studies on ectoparasites of birds should be conducted in the future since available data locally is still low.

\section{ACKNOWLEDGEMENTS}

Thanks to the Sarawak Forest Department for the permission (NPW.907.4.4(Jld.15)-5 and WL17/2018) to conduct this research. Thanks also to Universiti Malaysia Sarawak, Faculty Resource Science and Technology, lecturers, research team, postgraduate students and staffs for their assistance. The appreciation also dedicated to all who directly or indirectly lent their hand in this venture.

\section{REFERENCES}

Asrif, N. A., Nurqamareena, K., \& Chong, Y. L. (2018). Ectoparasites of Birds from a Rice Field in Samarahan Division, Sarawak. Trends in Undergraduate Research, 1(1), a45-51.

Atyeo, W. T., \& Peterson, P. C. (1970). Acarina: Astigmata: Analgoidea: feather mites of South Georgia and Heard Islands. Pacific Insects Monograpgh, 23, 121-151.

Barrientos, R., Valera, F., Barbosa, A., Carrillo, C. M., \& Moreno, E. (2014). Biogeography of haemo-and ectoparasites of an arid-land bird, the Trumpeter finch. Journal of Arid Environments, 106, 11-17.

Brown, C. R., Brown, M. B., \& Rannala, B. (1995). Ectoparasites reduce long-term survival of their avian host. Proceedings of The Royal Society B: Biological Sciences, 262(1365), 313-319.

Clayton, D. H., Koop, J. A. H., Harbison, C. W., Moyer, B. R., \& Bush, S. E. (2010). How birds combat ectoparasites. The Open Ornithology Journal, 3(1), 41-71.

Constantinescu, I. C., Chişamera, G., Mukhim, D. K. B., \& Adam, C. (2014). A new species of pterodectine feather mites (Acarina, Analgoidea, Proctophyllodidae) from the Little Spiderhunter Arachnothera longirostra (Passeriformes, Nectariniidae) in Meghalaya, India. ZooKeys, 425, 1-13.

Dalsgaard, B., Carstensen, D. W., Maruyama, P. K., Rahbek, C., Sandel, B., Sonne, J., Svenning, J., Wang, Z., \& Sutherland, W. J. (2014). Determinants of bird species richness, endemism, and island network roles in Wallacea and the West Indies: is geography sufficient or does current and historical climate matter. Ecology and Evolution, 4(20), 4019-4031.

Davison, G., \& Chew, Y. (2016). Birds of Borneo Sabah, Sarawak, Brunei and Kalimantan. London: Bloomsbury.

Dobson, A. P., \& Carper, R. E. (1996). Infectious disease and human population history. Bioscience, 46, $115-125$.

Fromont, E., Morvilliers, L., Artois, M., \& Pontier, D. (2001). Parasite richness and abundance in insular and mainland feral cats: insularity or density. Parasitology, 123(2), 143-151.

Galván, I., Barba, E., Piculo, R., Cantó, J. L., Cortés, V., Monrós, J. S., Atiénzar, F., \& Proctor, H. (2008). Feather mites and birds: an interaction mediated by uropygial gland size. Journal of Evolutionary Biology, 21(1), 133-144.

Hammer, O. (2000). Spatial organisation of tubercules and terrace lines in Paradoxides forchhammeri evidence of lateral inhibition. Acta Palaeontologica Polonica, 45, 251-270.

Hellgren, O., Križanauskiene, A., Hasselquist, D., \& Bensch, S. (2011). Low haemosporidian diversity and one key-host species in a bird malaria community on a mid-Atlantic island (São Miguel, Azores). Journal of Wildlife Diseases, 47(4), 849-859. 
Hughes, J., \& Page, R. D. (2007). Comparative tests of ectoparasite species richness in seabirds. $B M C$ Evolutionary Biology, 7(1), 227.

Johnson, K. P., \& Clayton, D. H. (2003). The biology, ecology, and evolution of chewing lice. Illinois Natural History Survey Special Publication, 24, 449-476.

Kalmar, A., \& Currie, D. J. (2006). A global model of island biogeography. Global Ecolological Biogeography, $15,72-81$

Kier, G., Kreft, H., Lee, T. M., Jetz, W., Ibisch, P. L., Nowicki, C., Mutke, J., \& Barthlott, W. (2009). A global assessment of endemism and species richness across island and mainland regions. Proceedings of the National Academy of Sciences, 106(23), 9322-9327.

Lindström, K. M., Foufopoulos, J., Pärn, H., \& Wikelski, M. (2004). Immunological investments reflect parasite abundance in island populations of Darwin's finches. Proceedings of the Royal Society of London B: Biological Sciences, 271(1547), 1513-1519.

Lyra-Neves, R. M. D., Farias, Â. M., \& Telino-Júnior, W. R. (2003). Ecological relationships between feather mites (Acari) and wild birds of Emberizidae (Aves) in a fragment of Atlantic Forest in northeastern Brazil. Revista Brasileira de Zoologia, 20(3), 481-485.

Madinah, A., Abang, F., Mariana, A., \& Abdullah, M. T. (2011). Ectoparasites of small mammals in four localities of wildlife reserves in Peninsular Malaysia. The Southeast Asian Journal of Tropical Medicine and Public Health, 42(4), 803-813.

Marshall, A. G. (1981). The Ecology of Ectoparasitic Insects. London: Academic Press.

McCoy, K. D., Léger, E., \& Dietrich, M. (2013). Host specialization in ticks and transmission of tick-borne diseases: a review. Frontiers in Cellular and Infection Microbiology, 3, 57.

Minorov, S. V., \& Kopij, G. (2000). New feather mites species of the genus Trouessartia (Acari: Analgoidea: Trouessartiidae) from South African passerines (Aves: Passeriformes). Mitteilungen aus dem Hamburgischen Museum and Institut, 97, 99-115.

Murray, M. D. (1990). Influence of host behaviour on some ectoparasites of birds and mammals. In C. J. Banard \& J. M. Behnke (Eds.), Parasitism and Host Behaviour (pp. 290- 315). New York: Taylor \& Francis.

Myers, S. (2016). Birds of Borneo (2nd ed.). London, UK: Bloomsburry Publishing Plc.

Paterson, V. L. (2012). Population dynamics of rodents and their parasite communities in a naturally fragmented landscape (Doctoral thesis). University of Glasgow, Scotland, UK.

Phillipps, Q., \& Phillipps, K. (2014). Phillipps' field guide to the birds of Borneo: Sabah, Sarawak, Brunei, Kalimantan (3rd ed.). United States: Princeton APPS.

Plaisance, L., Rousset, V., Morand, S., \& Littlewood, D. T. J. (2008). Colonization of Pacific islands by parasites of low dispersal ability: phylogeography of two monogenean species parasitizing butterflyfishes in the South Pacific Ocean. Journal of Biogeography, 35(1), 76-87.

Price, M. A., \& Graham, O. H. (1997). Chewing and sucking lice as parasites of mammals and birds. Beltsville: United State Department of Agriculture.

Rahman, W. A., \& Haziqah, F. (2015). Ectoparasitic fauna of scavenging chickens (Gallus domesticus). Malaysian Journal of Veterinary Research, 6(1), 33-42.

Reynold, S. (2013). The anatomy and histomorphology of the uropygial gland in New Zealand endemic species (Doctoral thesis). Massey University, Palmerston North, New Zealand.

Rozsa, L. (1997). Patterns in the abundance of avian lice (Phthiraptera: Amblycera, Ischnocera). Journal of Avian Biology, 249-254.

Rusli, N. H. (2007). Composition of avian ectoparasites in oil palm plantation and forest fragment. (Undergraduate thesis). University Malaysia Sarawak, Kota Samarahan, Malaysia.

Sajid, M., \& Ehsan, N. (2017). Insect ectoparasites on wild migratory birds: A review. Animal Science Journal, $8(1), 1-8$.

Simberloff, D. (1995). Why do introduced species appear to devastate islands more than mainland areas. Pacific Science, 49(1), 87-97.

Simberloff, D. (2000). Extinction-proneness of island species-causes and management implications. Raffles Bulletin of Zoology, 48(1), 1-9.

Sodhi, N. S. (2002). A comparison of bird communities of two fragmented and two continuous Southeast Asian rainforests. Biodiversity \& Conservation, 11(6), 1105-1119.

Stanko, M., Miklisová, D., de Bellocq, J. G., \& Morand, S. (2002). Mammal density and patterns of ectoparasite species richness and abundance. Oecologia, 131(2), 289-295.

Stettenheim, P. R. (2000). The integumentary morphology of modern birds - an overview. American Zoology, 40, 461-477.

Tschirren, B., Bischoff, L. L., Saladin, V., \& Richner, H. (2007). Host condition and host immunity affect parasite fitness in a bird-ectoparasite system. Functional Ecology, 21(2), 372-378.

Tuen, A. A., Das, I., Rahman, M. A., Abdullah, M. T., Marni, W., Ketol, B., \& Sait, I. (2006). The vertebrate fauna of Mount Berumput, Sarawak. In I. B. Ipor, C. S. Tawan, P. Bulan, I. Jusoh, B. A. Fasihuddin, \& K. Meekiong 
(Eds.), Proceeding of Conference on Natural Resources in the Tropics: Development and Commercialization of Tropical Natural Resources (pp. 161-168). Sarawak, Malaysia: Universiti Malaysia Sarawak.

Van Liere, D. W. (1992). The significance of fowl's bathing in dust. Animal Welfare, 1, 187-202.

Whelan, C. J., Wenny, D. G., \& Marquis, R. J. (2008). Ecosystem services provided by birds. Annals of The New York Academy of Sciences, 1134(1), 25-60.

Zarith, Z. M., Suhaila, A. H., Izzauddin, N. H. N. A. I., \& Khadijah, S. (2017). Parasites prevalence in poultry: focusing on free range turkeys (Meleagris gallopavo). Malaysian Journal of Veterinary Research, 8(1), 1-9. 